\title{
Proliferasi Tunas Adventif Tagetes (Tagetes erecta L.) Kultivar African Crackerjack dengan BAP, GA3, dan IAA Secara In Vitro
}

\author{
In Vitro proliferation of adventitious shoots of Tagetes (Tagetes $\underline{\text { erecta }}$ L.) var. African Crackerjack by \\ combination BAP, GA3, and IAA
}

\section{Muhammad Baidowi dan Ni Made Armini Wiendi*}

\author{
Departemen Agronomi dan Hortikultura, Fakultas Pertanian, Institut Pertanian Bogor \\ (Bogor Agricultural University), Jl. Meranti, Kampus IPB Darmaga, Bogor 16680, Indonesia \\ Telp.\&Faks.62-251-8629353 e-mail agronipb@indo.net.id \\ *Penulis untuk korespondensi : arminiwiendi@yahoo.co.id
}

Disetujui 16 Januari 2017/ Published Online 24 Januari 2017

\begin{abstract}
The main objective of this research was to observe the adventitious shoot proliferation of different explants (epycotil, cotyledon, hypocotyl) Tagetes (Tagetes erecta L.) with combination of PGR (BAP, GA3, and IAA). The first experiment was focused on seed sterilization. Epycotil was the only one explant that successfully differentiated into shoots, callus from hypocotyl and cotyledon were not differentiated into shoots due to phenolic. Combination BAP and IAA induced $70.7 \%$ callus from epicotyl, $49.3 \%$ callus from cotyledon, and 53\% callus from hypocotyl. Combination BAP and GA3 induced $60 \%$ callus from epicotyl, $48 \%$ callus from cotyledon, and $46 \%$ callus from hypocotyl. The result of experiment number two showed that the best media for adventitious shoot proliferation from epycotil are MS with $0.87 \mathrm{mg}^{-1} I A A+0.5 \mathrm{mg}$ $L^{-1} B A P$ and $M S$ with $0.43 \mathrm{mg} \mathrm{L}^{-1} I A A+0.5 \mathrm{mg} \mathrm{L}^{-1} B A P$. On the experiment number three showed that the best media for adventitious shoot proliferation from epycotil are MS with $1.73 \mathrm{mg} L^{-1} G A 3+1.5 \mathrm{mg} L^{-1} B A P$. Combination among GA3 and BAP were not significantly influence to the all variable. The result of experiment number two showed IAA influenced to callus-derived (at one week after treated), the number of adventitious shoots (at 3 weeks after treated), and leaves induced (at 4 and 5 weeks after treated). BAP significantly influenced to callus induced (at one week after treated), callus developed adventitious shoots (at 3 week after treated), and the number of adventitious shoot (at 3 week after treated). Experiment three showed that rooting was influenced by GA3 at 4 week and 5 week after treated, and BAP influenced the differentiation of callus from epicotyl to adventitious shoots at 3 week after treated.
\end{abstract}

Keyword: BAP, GA3, IAA, Proliferasi, Tagetes erecta L.

\section{ABSTRAK}

Tujuan penelitian ini mempelajari proliferasi tunas adventif eksplan hipokotil, epikotil, dan kotiledon Marigold (Tagetes erecta L.) secara in vitro dengan kombinasi BAP, GA3, dan IAA. Percobaan pertama adalah mengenai sterilisasi benih. Eksplan percobaan dua dan tiga adalah epikotil, hipokotil, dan kotiledon dari kecambah aseptik. Eksplan epikotil berhasil terproliferasi sedangkan hipokotil dan kotiledon tidak terproliferasi karena oksidasi fenol. Interaksi BAP dan IAA berpengaruh nyata pada induksi kalus epikotil pada semua minggu pengamatan, sedangkan interaksi BAP dan GA3 tidak berpengaruh nyata pada semua parameter. Komposisi media MS ditambah IAA dan BAP berhasil menginduksi kalus $70.7 \%$ dari eksplan epikotoil, 49.3\% dari eksplan kotiledon, 53\% dari hipokotil. Komposisi media MS ditambah GA3 dan BAP berhasil menginduksi kalus $60 \%$ dari eksplan epikotoil, 48\% dari eksplan kotiledon, 46\% dari hipokotil. Pada percobaan dua, media MS dengan $0.87 \mathrm{mg} \mathrm{L}^{-1} I A A+0.5 \mathrm{mg} \mathrm{L}^{-1}$ BAP dan media MS dengan $0.43 \mathrm{mg} \mathrm{L}^{-1} \mathrm{IAA}+0.5 \mathrm{mg} \mathrm{L}^{-1}$ BAP terbaik dalam menginduksi tunas adventif eksplan epikotil. Pada percobaan tiga, proliferasi tunas adventif tertinggi pada media MS dengan $1.73 \mathrm{mg} \mathrm{L}^{-1} \mathrm{GA3}+1.5 \mathrm{mg} \mathrm{L}^{-1}$ BAP. IAA berpengaruh nyata pada eksplan bertunas pada satu 1 MSP, tunas per eksplan pada 3 MSP, dan daun pertunas pada 4 MSP dan 5 MSP, sedangkan BAP berpengaruh nyata pada induksi kalus pada 1 MSP, eksplan bertunas pada 3 MSP, dan tunas per eksplan pada 3 MSP. Pada percobaan tiga, GA3 berpengaruh nyata pada pembentukan akar pada 4 MSP dan 5 MSP, sedangkan BAP berpengaruh nyata pada proliferasi tunas per eksplan pada 3 MSP.

Kata kunci : BAP, GA3, IAA, Proliferasi, Tagetes erecta L. 


\section{PENDAHULUAN}

Tagetes sp. memiliki banyak kegunaan antara lain sebagai antinematoda, antimikroba, antiinflamantori, antibakteri, fungisida, herbisida, malarisida, kosmetik, dan pewarna alami (Vasudevan et al., 1997; Tomova et al., 2005; Hook et al., 2010; Moetamadi et al., 2015; Karwani dan Sisodia, 2015). Studi etnobotani yang dilakukan di berbagai negara (Meksiko, India, Pakistan, dan Indonesia) melaporkan bahwa Tagetes sp. merupakan salah satu tanaman yang digunakan sebagai obat tradisional dan upacara keagamaan (Hernandes et al., 2003; Susiarti, 2006; Qureshi et al., 2007; Rajakumar dan Shivanna, 2009; Surata et al., 2015). Tagetes sp. yang mengandung minyak esensial yang dapat dimanfaatkan secara luas tersebut mengindikasikan kebutuhan akan bibit tanaman ini cukup besar. Menurut Cornelius dan Wycliffe dalam Preedy (2016) melaporkan pertumbuhan produksi minyak Tagetes sp. di dunia mengalami kemajuan pesat dari 1.5 ton/tahun pada tahun 1984 menjadi 15 ton/tahun pada tahun 2015 dengan harga berkisar US\$50- US\$155 per kilogram. Negara produsen terbesar minyak Tagetes sp. adalah Mesir, Zimbabwe, Nepal, India dan Australia. Indonesia belum mampu memproduksi minyak Tagetes sp. dan mengekspor bahan mentah (bibit, benih, maupun bunga). Petani di Indonesia memperbanyak Tagetes sp. secara in vivo dan konvensional, baik dengan biji atau stek yang dinilai kurang efesien secara teknis, waktu, ekonomi, dan tidak mampu menghasilkan tanaman dengan kapasitas besar dan seragam dalam waktu yang cepat. Perbanyakan secara in vitro dengan teknik kultur jaringan perlu dilakukan. Perbanyakan Tagetes sp. secara kultur jaringan sudah banyak dikembangkan di luar negeri namun di Indonesia belum dilakukan. Kultur jaringan dengan tujuan proliferasi merupakan salah satu teknik dalam perbanyakan tanaman secara klonal untuk perbanyakan masal. Keuntungan pengadaan bibit melalui kultur jaringan antara lain dapat diperoleh bahan tanaman yang bermutu dalam jumlah banyak dan seragam, selain itu diperoleh propagula (mother stock) sehingga dapat digunakan sebagai bahan untuk perbanyakan selanjutnya (Wattimena et al., 2011).

Keberhasilan proliferasi seringkali bergantung pada jenis tanaman, media, dan sumber eksplan. Media seringkali disesuaikan dengan tujuan pengkulturan. Kombinasi ZPT seperti auksin, giberelin, dan sitokinin sering digunakan dalam penelitian kultur jaringan untuk tujuan proliferasi (Wiendi et al., 1991).
Berdasarkan beberapa penelitian melaporkan bahwa beberapa spesies Tagetes sp. diperbanyak secara in vitro pada beberapa komposisi media dan sumber eksplan yang berbeda. Belarmino et al. (1992) melaporkan bahwa komposisi MS dengan penambahan kombinasi NAA $\left(0.2 \mathrm{mg} \mathrm{L}^{-1}\right.$, $\left.0.5 \mathrm{mg} \mathrm{L}^{-1}, 1.0 \mathrm{mg} \mathrm{L}^{-1}, 2.0 \mathrm{mg} \mathrm{L}^{-1}, 5.0 \mathrm{mg} \mathrm{L}^{-1}\right)$ dan BAP $\left(0.2 \mathrm{mg} \mathrm{L}^{-1}, 0.5 \mathrm{mg} \mathrm{L}^{-1}, 1.0 \mathrm{mg} \mathrm{L}^{-1}, 2.0 \mathrm{mg}\right.$ $\mathrm{L}^{-1}, 5.0 \mathrm{mg} \mathrm{L}^{-1}$ ) dapat menginduksi kalus eksplan daun dan hipokotil $T$. erecta. Hasil penelitian Osman et al. (2012) memperkuat dugaan bahwa media berpengaruh terhadap proliferasi Tagetes sp. Osman et al. (2012) melaporkan perlakuan kondisi terang dan gelap dengan media MS dengan penambahan NAA $\left(0.5 \mathrm{mg} \mathrm{L}^{-1}, 7.0 \mathrm{mg} \mathrm{L}^{-1}\right.$, $\left.10.0 \mathrm{mg} \mathrm{L}^{-1}\right)$ dan BAP $\left(5 \mathrm{mg} \mathrm{L}^{-1}, 10 \mathrm{mg} \mathrm{L}^{-1}, 15\right.$ $\mathrm{mg} \mathrm{L}^{-1}$ ) dapat memacu induksi kalus $T$. erecta dan T. patula dari eksplan daun, akar, dan batang. Selain ditumbuhkan pada komposisi media MS dengan penambahan auksin dan sitokinin, proliferasi tunas adventif $T$. erecta dapat dipacu dengan komposisi media MS dengan penambahan giberelin dan sitokinin. Misra dan Datta (2001) melaporkan bahwa media MS dengan penambahan $3.46 \mathrm{mg} \mathrm{L}^{-1} \mathrm{GA} 3+0.22 \mathrm{mg} \mathrm{L}^{-1} \mathrm{BA}$ berhasil memacu organogenesis daun T. erecta. Selain dipengaruhi oleh media, proliferasi Tagetes sp. dipengaruhi oleh jenis eksplan. Eksplan merupakan bagian dari tanaman baik dari tingkat sel maupun jaringan yang diisolasi untuk dijadikan sebagai bahan tanam secara in vitro. Jaringan meristematik yang berasal dari sel somatik umum digunakan dalam upaya multiplikasi eksplan tanpa merubah susunan genetik. Jaringan muda yang umum dipakai dari organ kecambah yaitu kotiledon, hipokotil, dan epikotil (Campbell et al., 2008). Mohamed et al. (1999) melaporkan mikropropagasi hipokotil dan kotiledon T. minuta menghasilkan kalus pada komposisi media MS dengan penambahan kombinasi IAA $\left(1 \mathrm{mg} \mathrm{L}^{-1}, 3 \mathrm{mg} \mathrm{L}^{-1}, 5 \mathrm{mg} \mathrm{L}^{-1}\right)$ dan NAA $\left(1 \mathrm{mg} \mathrm{L}^{-1}, 3 \mathrm{mg} \mathrm{L}^{-1}, 5 \mathrm{mg} \mathrm{L}^{-1}\right)$ dengan BA (1 $\left.\mathrm{mg} \mathrm{L} \mathrm{L}^{-1}, 5 \mathrm{mg} \mathrm{L}^{-1}, 10 \mathrm{mg} \mathrm{L}^{-1}, 15 \mathrm{mg} \mathrm{L}^{-1}\right)$. Sementara Miranda-ham et al. (2006) melaporkan eksplan meristem apeks $T$. erecta tumbuh menjadi kalus dan terdeferensiasi menjadi tunas pada komposisi media MS dengan penambahan kombinasi IAA $\left(1.75 \mathrm{mg} \mathrm{L}^{-1}, 5.25 \mathrm{mg} \mathrm{L}^{-1}\right)$ dengan BA $\left(6.75 \mathrm{mg} \mathrm{L}^{-1}, 11.25 \mathrm{mg} \mathrm{L}^{-1}, 11.75 \mathrm{mg} \mathrm{L}^{-1}\right)$. Penelitian lebih lanjut untuk mempelajari pengaruh auksin, sitokinin, dan giberelin pada sumber eksplan $T$. erecta yang berbeda perlu dilakukan sebagai rujukan untuk memproduksi bibit klonal $T$. erecta yang bermutu secara efektif. Penelitian ini bertujuan untuk mempelajari kemampuan proliferasi eksplan hipokotil, pucuk (epikotil), dan kotiledon Tagetes 
(Tagetes erecta L.) kultivar African Crackerjack melalui induksi tunas adventif secara in vitro dengan penambahan zat pengatur tumbuh BAP, GA3, dan IAA.

\section{METODE PENELITIAN}

Penelitian ini bertujuan untuk mempelajari kemampuan proliferasi eksplan hipokotil, pucuk (epikotil), dan kotiledon Tagetes (Tagetes erecta L.) kultivar African Crackerjack melalui induksi tunas adventif secara in vitro dengan penambahan zat pengatur tumbuh BAP, GA3, dan IAA. Bahan sterilan yang digunakan pada semua percobaan adalah Clorox dengan bahan aktif Natrium Hipoklorat $\left(\mathrm{NaClO}_{3}\right)$ yang dilarutkan dalam air steril. Bahan tanaman pada percobaan satu (sterilisasi) adalah benih Tagetes (Tagetes erecta L.) kultivar African Crackerjack, sedangkan bahan tanaman yang dipakai pada percobaan dua dan tiga (percobaan proliferasi) adalah eksplan dari kecambah aseptik Tagetes yaitu epikotil, kotiledon, dan hipokotil yang berumur 7 hari setelah ditumbuhkan pada media komposisi MS tanpa zat pengatur tumbuh. Bahanbahan penunjang lain yang digunakan pada penelitian ini diantaranya adalah aquades, spirtus, alkohol $70 \%$, tissue, plastik wrap, botol kultur. Sementara alat-alat percobaan yang digunakan pada penelitian ini diantaranya alat-alat kultur, autoclave, dan Laminar Air Flow Cabinet.

Pengembangan protokol sterilisasi benih Tagetes (Tagetes erecta L.) kultivar African Crackerjack

Percobaan ini didesain menggunakan Rancangan Acak Lengkap (RAL) dengan 1 faktor. Faktor perlakuan adalah metode sterilisasi benih. Terdapat 4 perlakuan dengan masing-masing perlakuan terdiri dari 4 ulangan. Setiap ulangan terdiri dari 5 benih sebagai satuan amatan sehingga total satuan amatannya adalah 80 satuan amatan. Perlakuan sterilisasi dilakukan dua tahap perendaman untuk setiap perlakuan. Perlakuanperlakuan pada percobaan sterilisasi benih disajikan pada Tabel 1.

Tabel 1. Perlakuan percobaan sterilisasi benih Tagetes (Tagetes erecta L.) kultivar African Crackerjack

\begin{tabular}{|c|c|c|}
\hline Perlakuan & Perendaman ke-satu & Perendaman ke-dua \\
\hline P0: & $100 \mathrm{ml}$ Air Steril (0\% clorox) selama 15 menit & - \\
\hline P1: & $70 \mathrm{ml}$ Air Steril + $30 \mathrm{ml}$ clorox (15 menit) & $\begin{array}{l}90 \mathrm{ml} \text { Air Steril }+10 \mathrm{ml} \text { clorox } \\
\text { (5 menit) }\end{array}$ \\
\hline P2: & $50 \mathrm{ml}$ Air Steril + $50 \mathrm{ml}$ clorox (15 menit) & $\begin{array}{l}90 \mathrm{ml} \text { Air Steril }+10 \mathrm{ml} \text { clorox } \\
(5 \text { menit })\end{array}$ \\
\hline P3: & $25 \mathrm{ml}$ Air Steril $+75 \mathrm{ml}$ clorox (15 menit) & $\begin{array}{l}90 \mathrm{ml} \text { Air Steril }+10 \mathrm{ml} \text { clorox } \\
\text { (5 menit) }\end{array}$ \\
\hline
\end{tabular}

Analisis data dilakukan dengan uji $\mathrm{F}$ taraf $5 \%$ dengan menggunakan program SAS (Statistical Analysis Sistem) 9.1.3. Jika berbeda nyata diuji lanjut menggunakan DMRT (Duncan Multiple Range Test).

Proliferasi tunas adventif Tagetes (Tagetes erecta L.) kultivar African Crackerjack dengan penambahan BAP dengan IAA

Percobaan kedua untuk mempelajari pengaruh komposisi media MS dengan penambahan kombinasi BAP dengan IAA terhadap proliferasi Tagetes (Tagetes erecta L.) kultivar African Crackerjack. Eksplan yang dipakai adalah bagian kecambah aseptik dari benih Tagetes yang terdiri dari epikotil, hipokotil, dan kotiledon. Percobaan kedua menggunakan Rancangan Acak Kelompok (RAK) faktorial dengan dua faktor dengan waktu penanaman sebagai kelompok. Pada percobaan kedua, faktor pertama adalah zat pengatur tumbuh BAP dengan 3 taraf : $0.5 \mathrm{mg} \mathrm{L}^{-1}, 1.0 \mathrm{mg} \mathrm{L}^{-1}, 1.5 \mathrm{mg} \mathrm{L}^{-1}$. Faktor kedua adalah zat pengatur tumbuh IAA dengan tiga taraf yaitu $0.43 \mathrm{mg} \mathrm{L}^{-1}, 0.87 \mathrm{mg} \mathrm{L}^{-1}, 1.30$ $\mathrm{mg} / \mathrm{L}$. Terdapat 9 perlakuan dengan 3 kali ulangan. Setiap ulangan terdiri dari 3 epikotil, 4 kotiledon, dan 4 hipokotil sebagai satuan amatan. Sehingga terdapat 297 satuan amatan. Perlakuanperlakuan pada percobaan kedua disajikan pada Tabel 2. 
Tabel 2. Perlakuan percobaan proliferasi tunas adventif Tagetes (Tagetes erecta L.) kultivar African Crackerjack dengan penambahan BAP dan IAA

\begin{tabular}{cccc}
\hline \multirow{2}{*}{ BAP $\left(\mathrm{mg} \mathrm{L}^{-1}\right)$} & \multicolumn{3}{c}{$\mathrm{IAA}\left(\mathrm{mg} \mathrm{L}^{-1}\right)$} \\
\cline { 2 - 4 } & $\mathrm{A} 1: 0.43 \mathrm{mg} \mathrm{L}^{-1}$ & $\mathrm{~A} 2: 0.87 \mathrm{mg} \mathrm{L}^{-1}$ & $\mathrm{~A} 3: 1.30 \mathrm{mg} \mathrm{L}^{-1}$ \\
\hline $\mathrm{B} 1: 0.5 \mathrm{mg} \mathrm{L}^{-1}$ & A1B1 & A2B1 & A3B1 \\
B2 $: 1.0 \mathrm{mg} \mathrm{L}^{-1}$ & A1B2 & A2B2 & A3B2 \\
B3 $: 1.5 \mathrm{~m} \mathrm{~L}^{-1}$ & A1B3 & A2B3 & A3B3 \\
\hline
\end{tabular}

Analisis data dilakukan dengan uji $\mathrm{F}$ taraf $5 \%$ dengan menggunakan program SAS (Statistical Analysis Sistem) 9.1.3. Jika berbeda nyata diuji lanjut menggunakan DMRT (Duncan Multiple Range Test).

Proliferasi tunas adventif Tagetes (Tagetes erecta L.) kultivar African Crackerjack dengan penambahan BAP dengan GA3

Percobaan ketiga untuk mempelajari pengaruh komposisi media MS dengan penambahan kombinasi BAP dengan GA3 terhadap laju proliferasi Tagetes (Tagetes erecta L.) kultivar African Crackerjack. Eksplan yang dipakai adalah bagian kecambah aseptik dari benih Tagetes yang terdiri dari epikotil, hipokotil, dan kotiledon. Percobaan ketiga disusun menggunakan Rancangan Acak Kelompok (RAK) faktorial dengan dua faktor. Waktu penanaman sebagai kelompok. Faktor pertama adalah zat pengatur tumbuh BAP dengan 3 taraf : $0.5 \mathrm{mg} \mathrm{L}^{-1}$, $1 \mathrm{mg} \mathrm{L}^{-1}, 1.5 \mathrm{mg} \mathrm{L}^{-1}$. Faktor kedua adalah zat pengatur tumbuh GA3 dengan tiga taraf yaitu 0.86 $\mathrm{mg} \mathrm{L}{ }^{-1}, 1.73 \mathrm{mg} \mathrm{L}^{-1}, 2.60 \mathrm{mg} \mathrm{L}^{-1}$. Terdapat 9 perlakuan dengan 3 kali ulangan. Setiap ulangan terdiri 3 epikotil, 4 kotiledon, dan 4 hipokotil sebagai satuan amatan. Sehingga terdapat 279 satuan amatan. Perlakuan pada percobaan ketiga disajikan pada Tabel 3.

Tabel 3. Perlakuan percobaan proliferasi tunas Adventif Tagetes (Tagetes erecta L) kultivar African Crackerjack dengan penambahan BAP dan GA3

\begin{tabular}{cccc}
\hline \multirow{2}{*}{ BAP $\left(\mathrm{mg} \mathrm{L}^{-1}\right)$} & \multicolumn{3}{c}{$\mathrm{GA} 3\left(\mathrm{mg} \mathrm{L}^{-1}\right)$} \\
\cline { 2 - 4 } & $\mathrm{C} 1: 0.86 \mathrm{~m} \mathrm{~L}^{-1}$ & $\mathrm{C} 2: 1.73 \mathrm{mg} \mathrm{L}^{-1}$ & $\mathrm{C} 3: 2.60 \mathrm{mg} \mathrm{L}^{-1}$ \\
\hline $\mathrm{B} 1: 0.5 \mathrm{mg} \mathrm{L}^{-1}$ & $\mathrm{C} 1 \mathrm{~B} 1$ & $\mathrm{C} 2 \mathrm{~B} 1$ & $\mathrm{C} 3 \mathrm{~B} 1$ \\
$\mathrm{~B} 2: 1.0 \mathrm{mg} \mathrm{L}^{-1}$ & $\mathrm{C} 1 \mathrm{~B} 2$ & $\mathrm{C} 2 \mathrm{~B} 2$ & $\mathrm{C} 3 \mathrm{~B} 2$ \\
$\mathrm{~B} 3: 1.7 \mathrm{mg} \mathrm{L}^{-1}$ & $\mathrm{C} 1 \mathrm{~B} 3$ & $\mathrm{C} 2 \mathrm{~B} 3$ & $\mathrm{C} 3 \mathrm{~B} 3$ \\
\hline
\end{tabular}

Analisis data dilakukan dengan uji $\mathrm{F}$ 5\% dengan menggunakan program SAS (Statistical Analysis Sistem) 9.1.3. Jika berbeda nyata diuji lanjut menggunakan DMRT (Duncan Multiple Range Test).

\section{HASIL DAN PEMBAHASAN}

Pengembangan Protokol Sterilisasi Benih Tagetes (Tagetes erecta L.) kultivar African Crackerjack

Perlakuan berpengaruh nyata terhadap persentase benih aseptik dan rata-rata jumlah benih yang berkecambah, namun tidak berpengaruh nyata terhadap waktu kecambah.
Tabel 4 menjelaskan bahwa peningkatan konsentrasi Natrium Hipoklorat $\left(\mathrm{NaClO}_{3}\right)$ dari $30 \%$ sampai $75 \%$ (P1, P2, P3) menekan angka kontaminasi dan meningkatkan daya kecambah, berbeda bila dibandingkan dengan kontrol (P0) yang tidak diberi perlakuan perendaman dengan desinfektan. Pada perlakuan ke-3 (P3) yaitu perlakuan dua kali perendaman yang terdiri dari perendaman pertama dengan $75 \%$ clorox (15 menit) dilanjutkan perendaman kedua dengan $10 \%$ clorox (10 menit) menunjukan jumlah benih berkecambah, waktu berkecambah, dan persentase benih aseptik terbaik dibandingkan dengan perlakuan yang lain, sehingga perlakuan ini dinilai paling efektif untuk sterilisasi benih Tagetes. 
Tabel 4. Data parameter percoban sterilisasi benih Tagetes (Tagetes erecta L.) kultivar African Crackerjack sampai 7 HST

\begin{tabular}{cccc}
\hline \multirow{2}{*}{ Perlakuan } & \multicolumn{3}{c}{ Parameter } \\
\cline { 2 - 4 } & Waktu Berkecambah (HST) & Persentase Kontaminasi (\%) & $\begin{array}{c}\text { Jumlah } \\
\text { Kecambah }\end{array}$ \\
\hline P0 & 3.5 & $70 \mathrm{~b}$ & $2.5 \mathrm{c}$ \\
P1 & 3.0 & $2.5 \mathrm{a}$ & $4.25 \mathrm{~b}$ \\
P2 & 3.0 & $0.0 \mathrm{a}$ & $5.0 \mathrm{a}$ \\
P3 & 3.0 & $0.0 \mathrm{a}$ & $5.25 \mathrm{a}$ \\
Uji F & tn & $* *$ & $* *$ \\
\hline
\end{tabular}

Bahan desinfektan yang diuji adalah clorox yang memiliki kandungan bahan aktif Natrium Hipoklorat $\left(\mathrm{NaClO}_{3}\right) 5 \%$. Nakagawara et al. (1998) melaporkan bahwa $\mathrm{NaClO}$ efektif membunuh berbagai macam tipe bakteri. Senyawa $\mathrm{NaClO}$ dilarutkan dalam air, garam hipokloritnya membentuk senyawa $\mathrm{HClO}$ yang dapat menyebabkan kerusakan DNA sehingga menyebabkan kematian sel bakteri (Dukan et al., 1999). Kontaminan bakteri pada penilitian dapat bersifat epiphytes atau endophytes (Sigee, 1993). Bakteri bersifat epiphytes merupakan bakteri yang menempel pada jaringan luar sel eksplan (Odutayo et al., 2007). Sementara bakteri endophytes merupakan bakteri yang tumbuh pada bagian ruang antar sel tanaman (Gunson dan Spencer-Phillips, 1994).

Perkecambahan. Setelah mendapatkan metode sterilisasi terbaik pada percobaan sterilisasi, benih disterilisasi dengan metode sterilisasi yang didapatkan pada percobaan sterilisasi, kemudian dikecambahkan pada media Murashige dan Skoog (MS) tanpa penambahan zat pengatur tumbuh dan dalam kondisi gelap sampai muncul kotiledon. Benih Tagetes sp. merupakan jenis benih yang memiliki struktur sisir pada pangkal biji. Hal ini menyebabkan tingginya faktor kontaminasi pada saat sterilisasi. Kontaminasi yang terjadi pada saat perkecambahan sebanyak $15 \%$ (Tabel 5). Kontaminan yang yang ditemukan pada saat perkecambahan adalah bakteri dan cendawan.

Letak embrionya sendiri berada di ujung berlawanan dari struktur sisir. Cahaya sangat mempengaruhi perkecambahan benih Tagetes erecta kul African Crackerjack. Munculnya kotiledon menandakan benih telah berkecambah secara sempurna. Kotiledon merombak cadangan makanan yang terdapat pada endospermae saat proses-proses awal perkecambahan sehingga benih bisa menjalankan proses fisiologi perkecambahan. Kotiledon yang berwarna kuning menandakan respon terhadap kebutuhan cahaya sehingga benih dipindahkan ke tempat terang agar tidak terjadi etiolasi.

Benih Tagetes (Tagetes erecta L.) kultivar African Crackerjack bersifat negatively photoblastic yang terhambat perkecambahannya karena faktor cahaya. Apabila benih dikecambahkan pada kondisi terang maka akan terjadi photodormancy. Cahaya berpengaruh terhadap aktivitas phytochrome. Phytochrome merupakan pigmen pada benih yang menginduksi embrio untuk menghasilkan hormon giberelin. Giberelin menginduksi terbentuknya enzim amylase yang memecah pati menjadi gula sehingga meningkatkan tekanan osmosis benih. Tekanan osmosis mengakibatkan pecahnya kulit benih dan memacu proses imbibisi sehingga terjadi perkecambahan (Toyomasu et al., 1998). Berdasarkan data yang diperoleh, benih dipindahkan pada 3 sampai 4 hari setelah perkecambahan (HSP). Sebanyak 79\% benih berhasil berkecambah dengan normal, sedangkan sisanya terjadi kontaminasi, etoliasi, dan mati (Tabel 5). Rata-rata benih berkecambah pada 3 HST. 
Tabel 5. Data fase perkecamabahan benih Tagetes (Tagetes erecta L.) kultivar African Crackerjack

\begin{tabular}{lccccccc}
\hline \multirow{2}{*}{\multicolumn{1}{c}{ Parameter }} & \multicolumn{7}{c}{ Hari Setelah Tanam (HST) } \\
\cline { 2 - 7 } & 1 & 2 & 3 & 4 & 5 & 6 & 7 \\
\hline Kecambah Muncul (\%) & 2 & 8 & 52.5 & 71.5 & 78.5 & 79.5 & 79.5 \\
Kecambah Sempurna (\%) & 0 & 2 & 5 & 50 & 73.5 & 75 & 79 \\
Kecambah Etiolasi (\%) & 0 & 0.5 & 0.5 & 8 & 8 & 8 & 8 \\
Kontaminasi (\%) & 0.5 & 6 & 6 & 11 & 15 & 15 & 15 \\
\hline
\end{tabular}

Percobaan proliferasi tunas adventif Tagetes (Tagetes erecta L.) kultivar African Crackerjack dengan penambahan BAP dan IAA

Induksi kalus. Kontaminasi bersumber dari tempat kultur dan media. Rentang persentase eksplan aseptik pada media kombinasi IAA dan BAP adalah 33\%-100\%. Secara berurutan rataan persentase eksplan aseptik untuk hipokotil, epikotil, dan kotiledon adalah $87 \%, 82 \%, 62 \%$. Data persentase eksplan epikotil, hipokotil, dan kotiledon aseptik disajikan pada Lampiran 2. Pengaruh perlakuan dengan IAA dan BAP pada induksi kalus hanya berpengaruh nyata terhadap eksplan epikotil, sedangkan pada eksplan kotiledon dan hipokotil tidak berpengaruh nyata. Interaksi IAA dan BAP berpengaruh nyata terhadap induksi kalus eksplan epikotil sampai 5 MSP, faktor tunggal IAA tidak berpengaruh nyata, sementara BAP berpengaruh nyata terhadap induksi kalus epikotil pada 1 MSP.

Tabel 6. Persentase kalus eksplan epikotil berkalus pada media MS dengan penambahan IAA dan BAP sampai 5 MSP

\begin{tabular}{cccccc}
\hline \multicolumn{2}{l}{ Perlakuan $\left(\mathrm{mg} \mathrm{L}^{-1}\right)$} & \multicolumn{3}{c}{ Eksplan berkalus (\%) } & Rata-Rata (\%) \\
\cline { 1 - 4 } IAA & BAP & Epikotil & Kotiledon & Hipokotil & 68 \\
\hline 0.43 & & 98 & 48 & 58 & 57 \\
0.87 & 0.5 & 84 & 36 & 50 & 59 \\
1.30 & & 56 & 42 & 78 & 62 \\
0.43 & & 73 & 75 & 37 & 37 \\
0.87 & 1.0 & 33 & 20 & 58 & 64 \\
1.30 & & 64 & 80 & 47 & 53 \\
0.43 & & 58 & 58 & 42 & 61 \\
0.87 & 1.5 & 80 & 58 & 45 & 60 \\
1.30 & & 91 & 27 & 62 & 57.8 \\
\hline Rata-rata (\%) & & 70.7 & 49.3 & 53.0 & \\
\hline
\end{tabular}

Tabel 6 menjelaskan bahwa perlakuan media dengan komposisi MS ditambah $0.43 \mathrm{mg} \mathrm{L}^{-}$ ${ }^{1} \mathrm{IAA}+0.5 \mathrm{mg} \mathrm{L}^{-1} \mathrm{BAP}$ menghasilkan rata-rata persentase kalus terbanyak pada semua jenis eksplan. Persentase eksplan epikotil, hipokotil, dan kotiledon membentuk kalus berada pada rentang 20\%-98\%. Hasil dari penelitian ini sama dengan penelitian Mohamed et al. (1999) bahwa 73\%-100\% eksplan kotiledon dan 60\%-100\% eksplan hipokotil $T$. minuta terproliferasi membentuk kalus pada perlakuan MS dengan kombinasi IAA $\left(1 \mathrm{mg} \mathrm{L}^{-1}, 3 \mathrm{mg} \mathrm{L}^{-1}, 5 \mathrm{mg} \mathrm{L}^{-1}\right)$ dan BA $\left(1 \mathrm{mg} \mathrm{L}^{-1}, 5 \mathrm{mg} \mathrm{L}^{-1}, 10 \mathrm{mg} \mathrm{L}^{-1}, 15 \mathrm{mg} \mathrm{L}^{-1}\right)$. Perlakuan dengan media MS dengan $1 \mathrm{mg} \mathrm{L}^{-1}$ $\mathrm{IAA}+10 \mathrm{mg} \mathrm{L}^{-1} \mathrm{BA}$ terbaik untuk menginduksi tunas T. minuta. Sementara Deka dan Arjuna (2014) melaporkan perlakuan MS dengan kombinasi $0.5 \mathrm{mg} \mathrm{L}^{-1}$ IAA dengan $5.0 \mathrm{mg} \mathrm{L}^{-1}$ Kinetin berhasil menginduksi kalus $100 \%$ dari eksplan daun $T$. erecta. Persentase kalus epikotil lebih tinggi dibanding hipokotil dan kotiledon diduga karena epikotil berada di daerah apeks yang merupakan tempat sintesis auksin sehingga memacu pembelahan sel yang lebih tinggi dibanding hipokotil dan kotiledon. BAP berpengaruh nyata terhadap induksi kalus diduga karena kemampuan sitokinin dalam memacu pembelahan sel, sehingga kalus akan mudah terbentuk dengan pemberian sitokinin (Arteca, 1995; Davies, 2004). Tekstur kalus yang 
didapatkan pada semua eksplan dan semua media perlakuan bertekstur kompak. Nikam dan Khan (2012) melaporkan 100\% kalus bertekstur kompak didapatkan pada kultur eksplan daun $T$. erecta yang ditumbuhkan pada perlakuan media MS dengan penambahan kombinasi IAA $(0.5 \mathrm{mg}$ $\left.\mathrm{L}^{-1}, 2.0 \mathrm{mg} \mathrm{L}^{-1}, 4.0 \mathrm{mg} \mathrm{L}^{-1}\right)$ dan BAP $\left(5.0 \mathrm{mg} \mathrm{L}^{-1}\right)$.

Tabel 7. Pengaruh interaksi IAA dan BAP terhadap induksi kalus eksplan epikotil Tagetes (Tagetes erecta L.) kultivar African Crackerjack pada setiap minggu pengamatan

\begin{tabular}{|c|c|c|c|c|c|c|}
\hline \multicolumn{2}{|c|}{ Perlakuan } & \multirow{2}{*}{\multicolumn{5}{|c|}{$\begin{array}{l}\text { Rata-rata jumlah epikotil berkalus } \\
\text { Minggu setelah perlakuan (MSP) }\end{array}$}} \\
\hline \multirow{2}{*}{ IAA $\left(\mathrm{mg} \mathrm{L}^{-1}\right)$} & \multirow{2}{*}{$\mathrm{BAP}\left(\mathrm{mg} \mathrm{L}^{-1}\right)$} & & & & & \\
\hline & & 1 & 2 & 3 & 4 & 5 \\
\hline 0.43 & \multirow{3}{*}{0.5} & $2.6 \mathrm{a}$ & $3.00 \mathrm{a}$ & $3.00 \mathrm{a}$ & $3.00 \mathrm{a}$ & $3.00 \mathrm{a}$ \\
\hline 0.87 & & $2.6 \mathrm{a}$ & $2.66 \mathrm{a}$ & $2.66 \mathrm{a}$ & $2.33 \mathrm{abc}$ & $2.33 \mathrm{abc}$ \\
\hline 1.30 & & $0.6 b c$ & $1.66 \mathrm{ab}$ & $1.33 b c$ & $1.33 \mathrm{bc}$ & $1.33 b c$ \\
\hline 0.43 & \multirow{3}{*}{1.0} & $1.3 \mathrm{~b}$ & $2.66 \mathrm{a}$ & $2.33 \mathrm{abc}$ & $2.33 \mathrm{abc}$ & $2.33 \mathrm{abc}$ \\
\hline 0.87 & & $0.0 \mathrm{c}$ & $1.00 \mathrm{~b}$ & $1.00 \mathrm{c}$ & $1.00 \mathrm{c}$ & $1.00 \mathrm{c}$ \\
\hline 1.30 & & $2.6 \mathrm{a}$ & $1.66 \mathrm{ab}$ & $2.00 \mathrm{abc}$ & $1.66 a b c$ & $1.66 \mathrm{abc}$ \\
\hline 0.43 & \multirow{3}{*}{1.5} & $1.3 b$ & $2.00 \mathrm{ab}$ & $2.00 \mathrm{abc}$ & $1.66 a b c$ & $1.66 \mathrm{abc}$ \\
\hline 0.87 & & $1.6 a b$ & $2.33 \mathrm{ab}$ & $2.66 a b$ & $2.66 a b$ & $2.66 a b$ \\
\hline 1.30 & & $2.6 \mathrm{a}$ & $3.00 \mathrm{a}$ & $2.66 \mathrm{ab}$ & $2.66 \mathrm{ab}$ & $2.66 \mathrm{ab}$ \\
\hline \multicolumn{2}{|c|}{ Uji F } & $* *$ & $*$ & $*$ & $*$ & $*$ \\
\hline \multicolumn{2}{|c|}{$\mathrm{KK}(\%)^{\mathrm{x})}$} & 25.4 & 35.6 & 30.1 & 22.3 & 21.3 \\
\hline
\end{tabular}

Keterangan: *= berpengaruh nyata pada taraf uji $5 \%, * *=$ berpengaruh nyata pada taraf uji $1 \%,{ }^{\mathrm{x})}=$ transformasi data $(\mathrm{x}+0.5)^{0,5}$

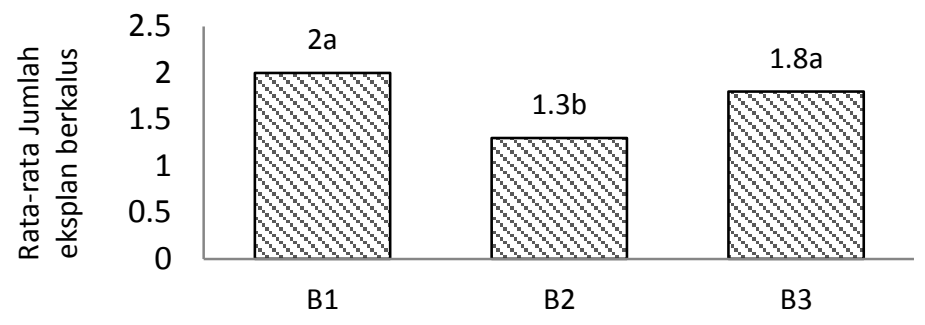

Keterangan:

Perlakuan BAP

B1: $0.5 \mathrm{mg} / \mathrm{L}$ BAP; B2: $1.0 \mathrm{mg} / \mathrm{L}$ BAP; B3: $1.5 \mathrm{mg} / \mathrm{L}$ BAP

Gambar 1. Pengaruh BAP terhadap jumlah eksplan berkalus dari epikotil Tagetes (Tagetes erecta L.) kultivar African Crackerjack pada satu minggu setelah perlakuan

Tabel 7 menjelaskan bahwa peningkatan konsentrasi BAP dan IAA tidak selalu meningkatkan persentase ekplan epokotil membentuk kalus. Meskipun perlakuan MS tanpa penambahan zat pengatur tumbuh tidak dapat menginduksi kalus T. erecta (Miranda-ham et al., 2006), adanya kemungkinan tingginya hormon endogen pada bagian meristm apek pada bagian epikotil sehingga ketika diberi hormon eksogen tidak selalu berpengaruh positif terhadap pertumbuhan tunas (Evans et al., 2003).

Gambar 1 menunjukan BAP berpengaruh nyata terhadap induksi kalus epikotil pada 1 MSP. Hasil uji lanjut menjelaskan perlakuan MS ditambah $1.0 \mathrm{mg} \mathrm{L}^{-1} \mathrm{BAP}$ cenderung lebih kecil dalam meningkatkan induksi kalus eksplan epikotil dibandingkan dengan perlakuan MS dengan $0.5 \mathrm{mg} / \mathrm{L}$ BAP dan perlakuan MS dengan $1.5 \mathrm{mg} / \mathrm{L}$ BAP.

Proliferasi tunas adventif. Kalus terdiferensiasi menjadi tunas didapatkan hanya pada eksplan epikotil, sedangkan untuk kalus kotiledon dan hipokotil tidak terjadi profilerasi membentuk tunas karena eksplan mati akibat senyawa fenolik. Proliferasi tunas adventif epikotil terjadi antara 1 MSP sampai 2 MSP. Interaksi IAA dan BAP dan faktor tunggal IAA dan BAP tidak berpengaruh nyata terhadap waktu proliferasi. Eksplan epikotil bertunas terbanyak didapatkan pada media MS dengan penambahan $0.43 \mathrm{mg} \mathrm{L}^{-1} \mathrm{IAA}+0.5 \mathrm{mg} \mathrm{L}^{-1}$ BAP, sedangkan jumlah tunas terbanyak didapatkan pada media MS dengan penambahan $0.87 \mathrm{mg} \mathrm{L}^{-1} \mathrm{IAA}+0.5$ mg L ${ }^{-1}$ BAP. 
Interaksi IAA dan BAP tidak berpengaruh nyata baik terhadap jumlah eksplan epikotil bertunas maupun jumlah tunas per eksplan. BAP berpengaruh nyata terhadap jumlah eksplan epikotil bertunas pada 3 MSP, sedangkan IAA berpengaruh nyata terhadap jumlah eksplan epikotil bertunas pada 1 MSP (Tabel 8). Sementara faktor tunggal IAA dan BAP berpengaruh nyata terhadap jumlah tunas per eksplan epikotil pada 3 MSP (Gambar 2).

Miranda-Ham et al. (2006) melaporkan proliferasi $70 \%$ tunas adventif tumbuh dari eksplan meristem apeks yang diberi perlakuan MS dengan penambahan $1.75 \mathrm{mg} \mathrm{L}^{-1} \mathrm{IAA}+15.75 \mathrm{mg}$
$\mathrm{L}^{-1}$ BA. Sementara hasil penelitian Qi et al. (2011) melaporkan $70 \%$ tunas adventif berhasil didapatkan dari kultur anther beberapa genotipe $T$. patula pada media MS dengan $0.5 \mathrm{mg} \mathrm{L}^{-1} \mathrm{NAA}+$ $0.5 \mathrm{mg} \mathrm{L}^{-1} \mathrm{BA}$.

Eksplan kotiledon dan hipokotil tidak terploriferasi karena terkena senyawa fenolik. Oksidasi fenol banyak ditemukan pada kultur Tagetes sp. Oksidasi fenol diduga karena eksplan menghasilkan senyawa polifenol seperti lignin, tanin, dan lainnya yang bisa bersifat antioksidan dan oksidatif yang sedang banyak dikembangkan di berbagai industri (Miranda-Ham et al., 2014; Nikam dan Khan, 2014).

Tabel 8. Faktor tunggal IAA dan BAP terhadap jumlah eksplan epikotil bertunas pada Tagetes (Tagetes erecta L.) kultivar African Crackerjack

\begin{tabular}{|c|c|c|c|c|c|}
\hline \multirow{3}{*}{ IAA $\left(\mathrm{mg} \mathrm{L}^{-1}\right)$} & \multicolumn{5}{|c|}{ Rata-rata jumlah eksplan epikotil bertunas } \\
\hline & \multicolumn{5}{|c|}{ Minggu Setelah Perlakuan (MSP) } \\
\hline & 1 & 2 & 3 & 4 & 5 \\
\hline 0.43 & $0.33 b$ & 1.77 & 2.11 & 2.44 & 2.22 \\
\hline 0.87 & $0.77 \mathbf{a b}$ & 2.44 & 2.66 & 2.77 & 2.66 \\
\hline 1.30 & $0.11 \mathrm{a}$ & 2.0 & 2.11 & 2.11 & 2.44 \\
\hline Uji F & $*$ & tn & tn & tn & tn \\
\hline $\mathrm{BAP}\left(\mathrm{mg} \mathrm{L}^{-1}\right)$ & \multicolumn{5}{|c|}{ Minggu Setelah Perlakuan (MSP) } \\
\hline 0.5 & 0.44 & 2.44 & $2.77 \mathbf{a}$ & 2.88 & 2.77 \\
\hline 1.0 & 0.55 & 1.77 & $1.89 b$ & 2.33 & 2.22 \\
\hline 1.5 & 0.22 & 2.0 & 2.22ab & 2.11 & 2.33 \\
\hline Uji F & tn & tn & $*$ & tn & tn \\
\hline $\mathrm{KK}(\%)^{\mathrm{x})}$ & 22.5 & 21.1 & 13.4 & 11.9 & 12.0 \\
\hline
\end{tabular}

Keterangan: $\mathrm{tn}=$ tidak berpengaruh nyata, $*=$ berpengaruh nyata pada taraf uji $5 \%,{ }^{\mathrm{x}}=$ transformasi data $(\mathrm{x}+0,5)^{0,5}$

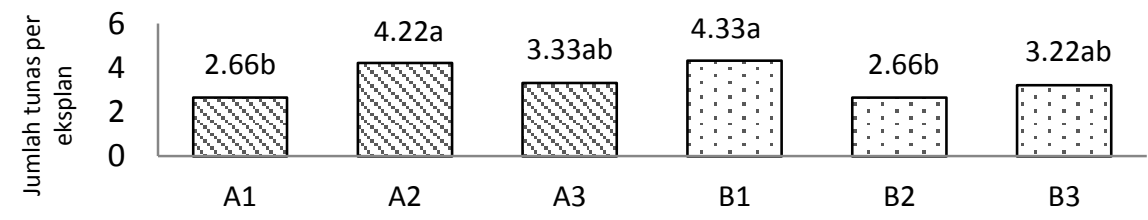

Keterangan:

Perlakuan IAA dan BAP

$\mathrm{A} 1=0.43 \mathrm{mg} / \mathrm{L} \mathrm{IAA} ; \mathrm{A} 2=0.87 \mathrm{mg} / \mathrm{L} \mathrm{IAA} ; \mathrm{A} 3=1.30 \mathrm{mg} / \mathrm{L}$ IAA

$\mathrm{B} 1=0.5 \mathrm{mg} / \mathrm{L}$ BAP $; \mathrm{B} 2=1.0 \mathrm{mg} / \mathrm{L}$ BAP $; \mathrm{B} 3=1.5 \mathrm{mg} / \mathrm{L}$ BAP

Gambar 2. Pengaruh faktor IAA dan BAP terhadap rata-rata jumlah tunas per eksplan epikotil Tagetes (Tagetes erecta L.) kultivar African Crackerjack pada 3 MSP

Gambar 2 menunjukan bahwa perlakuan media dengan $0.43 \mathrm{mg} \mathrm{L}^{-1}$ IAA dan $0.5 \mathrm{mg} \mathrm{L}^{-1}$ BAP menunujukan rata-rata jumlah tunas pereksplan tertinggi. Hal ini diduga karena sifat auksin untuk mengatur pemanjangan sel sehingga dapat memacu munculnya tunas dari kalus yang terbentuk. Sitokinin bersama auksin berperan dalam pertumbuhan tunas adventif pada kultur jaringan jika rasio auksin lebih rendah daripada sitokinin maka organogenesis mengarah ke tunas (Wiendi et al., 1991).
Daun per tunas. Interaksi IAA dan BAP tidak berpengaruh nyata terhadap jumlah daun per tunas eksplan epikotil. IAA berpengaruh nyata terhadap jumlah daun per tunas pada 3 MSP dan 4 MSP (Gambar 3). BAP tidak berpengaruh nyata terhadap jumlah daun per tunas. Tabel 9 menjelaskan bahwa rata-rata jumlah daun per tunas tertinggi sampai 5 MSP didapatkan pada perlakuan komposisi media MS dengan $0.43 \mathrm{mg}$ $\mathrm{L}^{-1} \mathrm{IAA}+1.0 \mathrm{mg} \mathrm{L}^{-1}$ BAP sebanyak 2.99 daun per tunas. 
Tabel 9. Rata-rata jumlah daun per tunas eksplan epikotil sampai 5 MSP pada beberapa perlakuan media MS dengan penambahan IAA dan BAP

\begin{tabular}{ccc}
\hline \multicolumn{1}{c}{ Perlakuan } & & Jumlah daun per tunas \\
\hline IAA $\left(\mathbf{m g ~ L}^{-\mathbf{1}}\right)$ & BAP $\left(\mathbf{m g ~ L}^{-\mathbf{1}}\right)$ & 2.02 \\
0.43 & 0.5 & 2.07 \\
0.87 & & 1.61 \\
1.30 & 1.0 & 2.99 \\
0.43 & & 1.65 \\
0.87 & & 1.43 \\
1.30 & 1.5 & 2.34 \\
0.43 & & 1.75 \\
0.87 & & 1.56 \\
1.30 & &
\end{tabular}

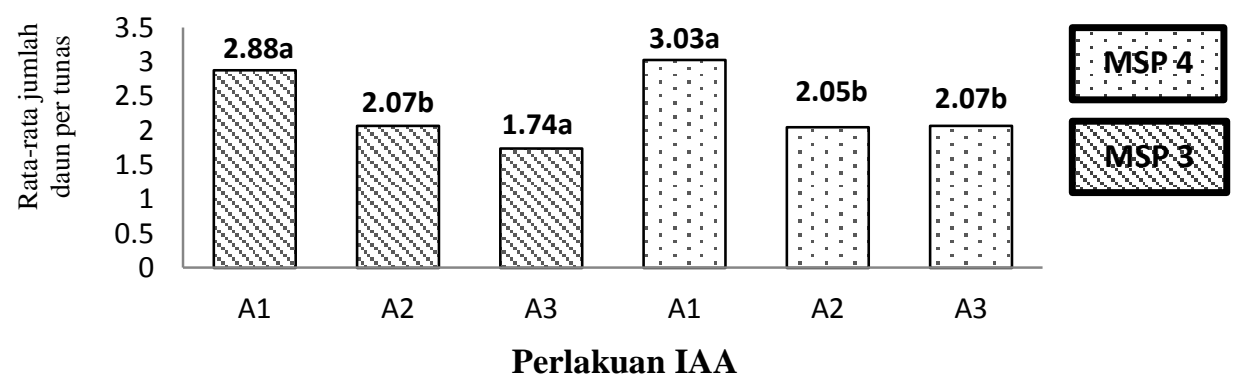

Keterangan:

$\mathrm{A} 1=0.43 \mathrm{mg} / \mathrm{L} \mathrm{IAA} ; \mathrm{A} 2=0.87 \mathrm{mg} / \mathrm{L} \mathrm{IAA} ; \mathrm{A} 3=1.30 \mathrm{mg} / \mathrm{L} \mathrm{IAA}$

MSP 3 = Minggu ke-3 setelah perlakuan

MSP 4 = Minggu ke-4 setelah perlakuan

Gambar 3. Pengaruh tunggal IAA terhadap jumlah daun per tunas dari eksplan epikotil Tagetes (Tagetes erecta L.) kultivar African Crackerjack pada 3 MSP dan 4 MSP

Gambar 3 menunjukan bahwa pada 3 MSP dan 4 MSP, faktor tunggal IAA berpengaruh nyata terhadap induksi daun eksplan epikotil. Peningkatan konsentrasi auksin cenderung menurunkan jumlah daun per tunas eksplan epikotil. Auksin bersifat dominansi apikal sehingga IAA cenderung menghambat pembentukan daun. Pergerakan auksin dalam jaringan tanaman bersifat polar (basipetal dan akropetal) yang mendukung dalam pemanjangan sel (cell elongation) diduga menjadi faktor tidak berkolerasi positifnya peningkatan konsentrasi IAA dengan jumlah daun per tunas (Wiendi et al., 1991; Wattimena et al., 1992; Arteca, 1995; Gaspar et al., 1996; Davies, 2004).
Pembentukan akar. Pemberian IAA maupun BAP secara tunggal maupun kombinasi keduanya tidak berpengaruh nyata terhadap pembentukan akar eksplan epikotil. Tabel 10 menjelaskan bahwa perlakuan dengan media 1.30 $\mathrm{mg} \mathrm{L} \mathrm{L}^{-1} \mathrm{IAA}+0.5 \mathrm{mg} \mathrm{L}^{-1}$ BAP menghasilkan jumlah rata-rata akar per tanaman tertinggi sebanyak 6.60. Belarmino et al. (1992) melaporkan bahwa perlakuan dengan komposisi MS ditambahkan dengan kombinasi $1.0 \mathrm{mg} \mathrm{L}^{-1}$ NAA dan $0.2 \mathrm{mg} \mathrm{L}^{-1} \mathrm{BA}$, dan MS ditambah 5.0 $\mathrm{mg} \mathrm{L}^{-1} \mathrm{NAA}+0.5 \mathrm{mg} \mathrm{L}^{-1} \mathrm{BA} 100 \%$ eksplan daun dan hipokootil $T$. erecta membentuk akar. 
Tabel 10. Rata-rata jumlah akar per eksplan epikotil sampai 5 MSP pada beberapa perlakuan media MS dengan penambahan IAA dan BAP

\begin{tabular}{|c|c|c|}
\hline \multicolumn{2}{|c|}{ Perlakuan } & \multirow{2}{*}{ Jumlah akar } \\
\hline IAA $\left(\mathrm{mg} \mathrm{L}^{-1}\right)$ & BAP $\left(\mathrm{mg} \mathrm{L}^{-1}\right)$ & \\
\hline 0.43 & & 4.60 \\
\hline 0.87 & 0.5 & 5.40 \\
\hline 1.30 & & 6.60 \\
\hline 0.43 & & 4.13 \\
\hline 0.87 & 1.0 & 5.13 \\
\hline 1.30 & & 3.67 \\
\hline 0.43 & & 4.27 \\
\hline 0.87 & 1.5 & 4.87 \\
\hline 1.30 & & 4.93 \\
\hline
\end{tabular}

Proliferasi tunas adventif Tagetes (Tagetes erecta L.) kultivar African Crackerjack dengan penambahan BAP dengan GA3

Induksi kalus. Rentang persentase eksplan aseptik epikotil, hipokotil, dan kotiledon adalah $33 \%-100 \%$. Secara berurutan rataan persentase eksplan aseptik untuk hipokotil, epikotil, dan kotiledon adalah $82 \%, 75 \%, 68 \%$. Interaksi BAP dan GA3 dan faktor tunggal keduanya tidak berpengaruh nyata terhadap persentase kalus pada eksplan kotiledon, hipokotil, dan epikotil. Ratarata persentase kalus secara berurutan untuk epikotil, hipokotil, dan kotiledon adalah $60 \%$, $48 \%$, dan $46 \%$ (dalam rentang 17\%-87\%). Perlakuan yang tertinggi untuk menginduksi kalus pada eksplan epikotil adalah media MS dengan $1.73 \mathrm{mg} \mathrm{L}^{-1} \mathrm{GA} 3+.5 \mathrm{mg} \mathrm{L}^{-1} \mathrm{BAP}$, sedangkan pada kotiledon dan hipokotil dengan perlakuan media MS dengan $0.86 \mathrm{mg} \mathrm{L}^{-1} \mathrm{GA} 3+1.5 \mathrm{mg} \mathrm{L}^{-1}$ BAP.
Proliferasi tunas adventif. Perlakuan media MS dengan penambahan kombinasi GA3 dan BAP berhasil memacu pembentukan tunas eksplan epikotil. Rata-rata persentase tertinggi eksplan epikotil membentuk tunas dan jumlah tunas per eksplan didapatkan pada perlakuan media MS dengan penambahan $1.73 \mathrm{mg} \mathrm{L}^{-1} \mathrm{GA} 3$ $+1.5 \mathrm{mg} \mathrm{L}^{-1}$ BAP. Interaksi GA3 dan BAP tidak berpengaruh nyata terhadap jumlah eksplan epikotil bertunas. Sementara faktor tunggal BAP berpengaruh nyata pada 4 MSP, namun GA3 tidak berpengaruh nyata. Interaksi GA3 dan BAP dan faktor tunggal GA3 tidak berpengaruh nyata terhadap pembentukan tunas per eksplan sampai 5 minggu pengamatan, sedangkan BAP berpengaruh nyata pada 3 MSP. BAP berpengaruh nyata terhadap proliferasi tunas adventif diduga karena BAP memacu pembelahan sel dan mempengaruhi lintasan diferensiasi sel tanaman (D'agostino dan Kieber, 1993; Gaspar et al., 1996; Davies, 2004).

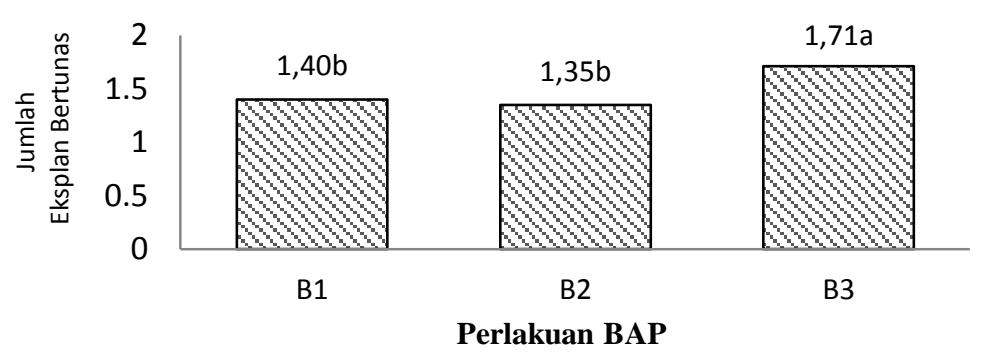

Keterangan:

$\mathrm{B} 1=0,5 \mathrm{mg} / \mathrm{L} \mathrm{BAP} ; \mathrm{B} 2=1,0 \mathrm{mg} / \mathrm{L} \mathrm{BAP} ; \mathrm{B} 3=1,5 \mathrm{mg} / \mathrm{L} \mathrm{BAP}$

Gambar 4. Pengaruh tunggal BAP terhadap jumlah eksplan epikotil bertunas Tagetes (Tagetes erecta L.) pada 4 MSP 
Tabel 11. Pengaruh faktor tunggal GA3 dan BAP terhadap jumlah tunas per eksplan Tagetes (Tagetes erecta L.) kultivar African Crackerjack

\begin{tabular}{|c|c|c|c|c|c|}
\hline \multirow{3}{*}{ GA3 $\left(\mathrm{mg} \mathrm{L}^{-1}\right)$} & \multicolumn{5}{|c|}{ Rata-rata jumlah tunas eksplan epikotil } \\
\hline & \multicolumn{5}{|c|}{ Minggu Setelah Perlakuan (MSP) } \\
\hline & 1 & 2 & 3 & 4 & 5 \\
\hline 0.86 & 1.06 & 1.25 & 1.54 & 1.83 & 2.02 \\
\hline 1.73 & 0.85 & 1.62 & 1.72 & 1.94 & 2.01 \\
\hline 2.60 & 0.91 & 1.53 & 1.65 & 1.71 & 1.73 \\
\hline Uji F & $\operatorname{tn}$ & $\operatorname{tn}$ & $\operatorname{tn}$ & $\operatorname{tn}$ & $\operatorname{tn}$ \\
\hline $\operatorname{BAP}\left(\mathrm{mg} \mathrm{L}^{-1}\right)$ & \multicolumn{5}{|c|}{ Minggu Setelah Perlakuan (MSP) } \\
\hline 0.5 & 0.98 & 1.52 & 1.64 & 1.78ab & 1.95 \\
\hline 1.0 & 0.85 & 1.41 & 1.52 & $1.64 b$ & 1.66 \\
\hline 1.5 & 0.98 & 1.47 & 1.75 & $2.05 a$ & 2.14 \\
\hline Uji F & tn & tn & tn & $*$ & tn \\
\hline $\mathrm{KK}(\%)^{\mathrm{x})}$ & 23.8 & 25.4 & 19.7 & 20.7 & 20.8 \\
\hline
\end{tabular}

Keterangan: $\mathrm{tn}=$ tidak berpengaruh nyata, $*=$ berpengaruh nyata pada taraf uji $5 \%$, $* *=$ berpengaruh nyata pada taraf uji $1 \%,{ }^{\mathrm{x}}=$ transformasi data $(\mathrm{x}+0,5)^{0,5}$

Daun per tunas. Pemberian GA3 maupun BAP secara tunggal maupun kombinasi keduanya tidak berpengaruh nyata terhadap pembentukan daun eksplan epikotil. Tabel 12 menjelaskan bahwa perlakuan dengan komposisi media MS ditambah $0.86 \mathrm{mg} \mathrm{L}^{-1} \mathrm{GA} 3+1.5 \mathrm{mg} \mathrm{L}^{-1}$ BAP menginduksi jumlah daun tunas per tunas tertinggi dibanding dengan perlakuan lain sebanyak 2.43.

Tabel 12. Rata-rata jumlah daun per tunas eksplan epikotil sampai 5 MSP pada beberapa perlakuan media MS dengan penambahan BAP dan GA3

\begin{tabular}{|c|c|c|}
\hline \multicolumn{2}{|c|}{ Perlakuan } & \multirow{2}{*}{ Jumlah daun per tunas } \\
\hline GA3 $\left(\mathrm{mg} \mathrm{L}^{-1}\right)$ & BAP $\left(\mathrm{mg} \mathrm{L}^{-1}\right)$ & \\
\hline 0.86 & \multirow{4}{*}{0.5} & 1.66 \\
\hline 1.73 & & 0.86 \\
\hline 2.60 & & 1.34 \\
\hline 0.86 & & 2.00 \\
\hline 1.73 & \multirow[t]{3}{*}{1.0} & 1.22 \\
\hline 2.60 & & 0.81 \\
\hline 0.86 & & 2.43 \\
\hline 1.73 & \multirow[t]{2}{*}{1.5} & 1.62 \\
\hline 2.60 & & 1.85 \\
\hline
\end{tabular}

Pembentukan akar. Perlakuan media MS dengan $1.73 \mathrm{mg} \mathrm{L}^{-1} \mathrm{GA} 3+1.5 \mathrm{mg} \mathrm{L}^{-1} \mathrm{BAP}$ menghasilkan rata-rata pembentukan akar eksplan epikotil tertinggi sampai 5 MSP. Interaksi GA3 dan BAP tidak berpengaruh nyata terhadap pembentukan akar. Faktor tunggal BAP tidak berpengaruh nyata terhadap pembentukan akar, sedangkan faktor tunggal GA3 berpengaruh nyata pada dua minggu terakhir pengamatan (Tabel 13). 
Tabel 13. Pengaruh faktor tunggal GA3 dan BAP terhadap rata-rata jumlah akar eksplan epikotil Tagetes (Tagetes erecta L.) kultivar African Crackerjack sampai 5MSP

\begin{tabular}{cccccc}
\hline \multirow{2}{*}{ Faktor } & \multicolumn{5}{c}{ Rata-rata jumlah akar } \\
\cline { 2 - 6 } & \multicolumn{5}{c}{ Minggu setelah perlakuan (MSP) } \\
\hline GA3 $\left(\mathrm{mg} \mathrm{L}^{-1}\right)$ & 1 & 2 & 3 & 4 & 5 \\
\hline 0.86 & 0.0 & 3.0 & 4.8 & $\mathbf{6 . 6 a}$ & $\mathbf{7 . 5 b}$ \\
1.73 & 0.0 & 3.1 & 5.0 & $\mathbf{6 . 8 a}$ & $\mathbf{7 . 7 a}$ \\
2.60 & 0.0 & 2.6 & 3.8 & $\mathbf{5 . 1 b}$ & $\mathbf{5 . 6 b}$ \\
$\mathrm{Uji} \mathrm{F}$ & tn & tn & tn & $*$ & $*$ \\
\hline BAP $\left(\mathrm{mg} \mathrm{L}^{-1}\right)$ & 0.0 & 2.6 & 4.0 & 6.0 & 7.0 \\
\hline 0.5 & 0.0 & 2.4 & 4.3 & 7.2 & 8.0 \\
1.0 & 0.0 & 3.7 & 5.4 & 5.4 & 6.0 \\
1.5 & tn & tn & tn & tn & tn \\
\hline $\mathrm{Uji} \mathrm{F}$ & 22.5 & 21.5 & 20.3 & 16.4 & 15.7 \\
\hline $\mathrm{KK}(\%)^{\mathrm{x}}$ & & &
\end{tabular}

Keterangan: Angka yang diikuti huruf yang sama pada kolom yang sama menunjukan tidak berbeda nyata pada uji Duncan taraf nyata $5 \% . \mathrm{tn}=$ tidak berpengaruh nyata. ${ }^{\mathrm{x}}=$ transformasi data $(\mathrm{x}+0.5)^{0.5}$

\section{KESIMPULAN}

Dari percobaan pengembangan protokol sterilisasi benih, didapatkan metode sterilisasi benih dengan perendaman $75 \%(\mathrm{v} / \mathrm{v})$ Natrium Hipoklorat $\left(\mathrm{NaClO}_{3}\right)$ selama 15 menit lalu direndam dengan $10 \%(\mathrm{v} / \mathrm{v})$ Natrium Hipoklorat $\left(\mathrm{NaClO}_{3}\right)$ selama 10 menit, terbaik untuk sterilisasi benih Tagetes (Tagetes erecta L.) kultivar African Crackerjack. Kontaminan pada penelitian ini terdiri dari bakteri dan cendawan.

Berdasarkan hasil percobaan dua dan tiga, didapatkan eksplan epikotil terbaik untuk proliferasi tunas adventif Tagetes (Tagetes erecta L.) kultivar African Crackerjack. Hipokotil dan kotiledon tidak terproliferasi karena tidak membentuk kalus maupun tunas adventif karena mati akibat terjadi oksidasi fenol. Interksi IAA dengan BAP berpengaruh nyata hanya pada induksi kalus pada eksplan epikotil, sementara interaksi GA3 dengan BAP tidak berpengaruh nyata pada semua parameter pengamatan.

Media MS dengan penambahan $0.43 \mathrm{mg}$ $\mathrm{L}^{-1} \mathrm{IAA}+0.5 \mathrm{mg} \mathrm{L}^{-1} \mathrm{BAP}$ dan media MS dengan penambahan $0.87 \mathrm{mg} \mathrm{L}^{-1} \mathrm{IAA}+0.5 \mathrm{mg} \mathrm{L}^{-1} \mathrm{BAP}$ terbaik dalam menginduksi tunas adventif eksplan epikotil. Proliferasi tunas adventif epikotil tertinggi juga didapatkan pada perlakuan media dengan komposisi MS ditambah $1.73 \mathrm{mg} \mathrm{L}^{-1} \mathrm{GA} 3$ $+1.5 \mathrm{mg} \mathrm{L}^{-1} \mathrm{BAP}$.

Faktor tunggal IAA berpengaruh nyata terhadap eksplan bertunas pada 1 MSP, jumlah tunas per eksplan pada $3 \mathrm{MSP}$, dan induksi daun pada 4 MSP dan 5 MSP, sedangkan GA3 berpengaruh nyata pada pembentukan akar pada 4 MSP dan 5 MSP. Pada percobaan dua, BAP berpengaruh nyata pada induksi kalus pada 3 MSP, eksplan berkalus pada 3 MSP, dan jumlah tunas adventif pada 3 MSP, sedangkan pada percobaan tiga BAP berpengaruh nyata terhadap jumlah tunas adventif pada 4 MSP.

\section{DAFTAR PUSTAKA}

Arteca, R.N. 1995. Plant Growth Subtances: Principle and Application. Chapman and Hall. New York. 332p Arteca R.N. 1995. Plant Growth Subtances: Principle and Application. Chapman and Hall. New York. 332p.

Belarmino, M.M., Abe, T., Sasahara, T. 1992. Callus induction and plant regeneration in African Tagetes (Tagetes erecta L.). Jap. J. Breed. 42(4): 835-841.

Campbell, N.A., Reece, J.B., Urry, L.A., Cain, M.L., Wasserman, S.A., Minorsky, P.V.,
Jackson, R.B. 2008. Biology. 8th Edition. Pearson Education. Inc. San Francisco. $1267 \mathrm{p}$.

Cornelius, W.W., Wycliffe, W. 2016. Tagetes (Tagetes minuta L.) Oils. In: Preedy, V.R. (Ed.), Essential Oils in Food Preservation, Flavor and Safety. Academic Press. 791802.

D’Agostino, I.B., Kieber, J.J. 1993. Molecular mechanisms of cytokinin action. Department of Biological Sciences. Laboratory for Molecular Biology. University of Illinois USA; Current 
Opinion in Plant Biology 1999. 2:359364.

Davies, P.J. 2004. Plant Hormones: Biosynthesis, transduction, action. Kluwer Academic Publisher. Dordrecht. 750p.

Deka, B., Arjuna, A. 2014. Effect of plant growth regulators on in vitro propagation of Tagetes erecta L. Int. J. Pharm. Bio. Sci. 5(2): $319-332$.

Dukan, S., Belkin, S., Touati, D. 1999. Reactive oxygen species are partially involved in the bactericidal action of hypochlorous acid. Arch. Biochem. Biophys. 367: 311316.

Evans, D.A., Coleman, J.O.D., Keams, A. 2003. Plant Cell Culture. BIOS Scientific Publisher. New York. 174p.

Gaspar, T., Kevers, C., Penel, C., Greppin, H., Reid, D.M., Thorpe, T.A. 1996. Plant Hormone and Plant Growth Regulators in Plant Tissue Culture. In Vitro Cell. Dev. Biol. Plant. 32:272-280.

Gunson, H.E., Spencer-Phillips. 1994. Latent bacrerial infections: Epiphytes and endophyres as contaminanrs of micropropagated plants. In: Physiology. Growth and Development of Plants in Culture. JR Nicholas. ed. Kluwer Academic Publishers. Dordrecht. Netherlands. 379-396.

Hernandez, T., Canales, M., Avila, J.G., Duran, A., Caballero, J., Romo de Vivar, A., Lira, R. 2003. Ethnobotany and antibacterial activity of some plants used in traditional medicine of Zapotitlán de las Salinas, Puebla (México). J. Etnopharmacology. 88: 181-188.

Hooks, C.R.R., Wang, K., Ploeg, A., McSolrey, R. 2010. Using Marigold (Tagetes spp.) as a cover crops from plant-parisitic nematodes. App. Soil. Eco. 46: 307-320.
Karwani, G., Sisodia, S.S. 2015. Tagetes erecta plant: Review with significant pharmacological activities. World. $J$. Pharma. Sci. 3(6): 1180-1183.

Miranda-Ham, M.L., Lizbeth, A., Castro-Concha, Avilez-Berzunza, A., Godoy-Hernanadez, G. 2006. Plant Regeneration of Shoot Apex-Derived Calluses of Marigold (Tagetes erecta L.). HortScience. 41(6): 1518-1520.

Misra, P., Datta, S.K. 1999. In vitro propagation of white Tagetes (Tagetes erecta L.) through shoot tip proliferation. Curr. Sci. 77:101-103.

Moetamadi, H., Sayyednejad, S.M., Bakhtiari, A., Vafaei, M. 2015. Tagetes erecta L., A Potential Medicinal Plant for Discovering a New Antibacterial Agent. Jentashapir. $J$. Health. Res. 6(4): 20-24.

Mohamed, M.A.H., Harris, P.J.C., Handerson. 1999. An efficient in vitro regeneration protocol for Tagetes minuta. Plant Cell, Tissue and Organ Culture. Kluwer Academic Publisher. 55: 211-215.

Nakagawara, S., Goto, T., Nara, M., Ozawa, Y., Hotta, K., Arata, Y. 1998. Spectroscopic characterization and the $\mathrm{pH}$ dependence of bactericidal activity of the aqueous chlorine solution. Anal. Sci. 14: 691698.Nikam, S.L., S.J. Khan. 2014. In vitro callus induction in leaf explants of Tagetes erecta L. Int. J. Pharma. Biosci. 5(4): 648-653.

Odutayo, O.I., Amusa, N.A., Okutade, O.O., Ogunsanwo, Y.R. 2007. Sources of microbial contamination in tissue culture laboratories in southwestern Nigeria. African. J. Agr. Res. 2(3): 67-072.

Osman, H.A., Taha, H.S., Youssef, M.M.A., ElGindi, A.Y., Ammen, H.H., Lushein, A.M.S. 2012a. Establishment of calli cultures from different explants of $T$. erecta and T. patula. J. App. Sci. Res. 8(7):

3850-3854. 
Qi Y., Ye Y., Bao M. 2011. Establishment of plant regeneration system from anther culture of Tagetes patula L.. Afr. J. Biotechnol. 10(75): 17332-17338.

Qureshi R.A., Ghufran M.A., Gilani S.A., Sultana K., Ashraf M. 2007. Ethnobotanical studies of selected medicinal plants of Sudhan Gali and Ganga Chotti Hills, district Bagh, Azad Kashmir. Pakistani. J. Bot. 39(7): 2275-2283.

Rajakumar N., Shivanna M.B. 2009. Ethnomedicinal application of plants in the eastern region of Shimoga district, Karnataka, India. J. Etnopharmacology. 126: 64-73.

Sigee D.C. 1993. Bacteria and Plant Pathoges. In: Bacterial Plant Pathology; Cell and Molecular Aspects. D.C. Sigee. ed. Cambridge University Press. Cambridge. 325 p.

Surata I.K., Gata I.W., Sudiana I.M. 2015. Studi Etnobotanik Tanaman Upacara Hindu Bali sebagai Upaya Pelestarian Kearifan Lokal. J. Kajian Bali. 5 : No.2.
Susiarti S. 2006. Pengetahuan dan pemanfaatan tumbuhan obat di Sabang - pulau Weh, Nangroe Aceh Darussalam. J. Tek. Ling (Edisi khusus). 198-199.

Tomova B.S., Waterhouse J.S., Doberski J. 2005. The effect of fractionated Tagetes oil volatiles on aphid reproduction. Entomol. Exp. Appl. 115: 153-159.

Toyomasu T., Kawaide H., Mitsihashi W., Inoue Y., Kamiya Y. 1998. Phytochrome regulates gibberillin biosynthesis during germination of photoblastic lettuce seeds. Plant Physiology. 118: 1517-1523.

Vasudevan P., Suman K., Satyawati S. 1997. Tagetes: A multipurpose plant. Bioresource Technology. 7: 29-35.

Wattimena G.A., Nurhajati A.M., Wiendi N.M.A., Purwito A., Efendi D., Purwoko B.S., Khumaida N. 2011. Bioteknologi: Dalam Pemuliaan Tanaman. IPB Press. Bogor.

Wiendi N.M.A., Wattimena G.A., Gunawan L.W. 1991. Perbanyakan Tanaman. Hal.17-44. Dalam Tim Laboratorium Kultur Jaringan Tanaman (Eds.). Bioteknologi Tanaman. Pusat Antar Universitas (PAU). Bogor. 